\title{
LANDLORD AND TENANT: LANDLORD HAS DUTY TO PROTECT TENANT FROM FORESEEABLE CRIMINAL ACTS OF INTRUDERS IN COMMON AREAS
}

In Kline v. 1500 Massachusetts Avenue Apartment Corp. ${ }^{1}$ the Court of Appeals for the District of Columbia Circuit held that a landlord has a duty to use reasonable care to safeguard his tenants from foreseeable criminal acts committed by third parties and to protect those parts of his premises which are not usually subject to periodic police patrol. In 1959, when the tenant first leased her apartment from the landlord, the main and garage entrances to the 585 unit complex were monitored at all times by building attendants; a third entrance was unguarded during the daylight hours but was locked after 9:00 P.M. By 1966, however, the main and garage entrances were frequently left unattended, and the third entrance often remained unlocked overnight. The tenant was injured seriously when she was criminally assaulted in the hallway of the apartment complex by an intruder. She sued the landlord, alleging that a series of assaults, robberies, and other criminal of fenses had occurred against tenants in the common areas of the apartment building since the slackening. of the security measures. ${ }^{2}$ The district court ruled as a matter of law that the landlord had no duty to protect his tenants from the foreseeable criminal acts of third parties. ${ }^{3}$ The court of appeals reversed and remanded for a determination of damages.

While in most instances one is not under a legal obligation to protect another from the activities of a third person, ${ }^{4}$ relationships do exist between parties of "such a character that the law imposes the affirmative duty upon one person to attempt to control another's conduct to avoid an unreasonable risk to a third person." Traditionally, this responsibility has been imposed, inter alia, upon

1. No. 23,401 (D.C. Cir. Aug. 6, 1970).

2. The dissenting judge asserted that the record showed but one prior asault and no robberies. Id. at 23.

3. Id.at 1 .

4. See W. Prosser, The Law of Torts § 54 (3d ed. 1964) [hereinafter cited as Prosser]; RESTATEMENT (SECOND) OF TORTS § 315 (1965); Harper \& Kime, The Duty to Control the Conduct of Another, 43 YALE L.J. 886 (1934).

5. Harper \& Kime, supra note 4, at 887. See also Prosser § 53, at 331; Restatement (SECOND) OF TORTS \& 314A, comment b (1965). 
carriers, ${ }^{6}$ innkeepers, ${ }^{7}$ schoolmasters,${ }^{8}$ storekeepers, ${ }^{9}$ and operators of recreational facilities. ${ }^{10}$ The duty arises because the individual has entrusted his comfort and safety to the care of the person who has a greater capacity to prevent disturbance or mishap due to his control over the premises or vehicle. " For example, in Gurren v. Casperson,12 a female guest requested that the hotel management protect her from the threats of another guest. When the management did not maintain surveillance over the belligerent guest who subsequently assaulted the plaintiff outside her door, the hotel owner was held liable for her injuries. In Fortney $v$. Hotel Rancroft, Inc. ${ }^{13}$ a guest locked his door, leaving his key with the clerk as he departed for the evening. When he reentered his locked room later that night, he was knocked unconscious by an intruder. Since no explanation was offered by the hotel as to how an intruder could pass the desk unnoticed, the court found the hotel owner negligent, emphasizing that the relationship of innkeeper and guest imposed a duty upon the defendant to use a "high degree of care"14 to secure the safety of its guests. Yet from the earliest days the courts have held that the landlord is not a guarantor of the safety of his premises or his tenants. ${ }^{15}$ This immunity of the landlord from the legal duties of the innkeeper and the carrier is largely explained by the agrarian past of the law of landlord and tenant, where, absent express covenants, the basic agreement between the parties was for the exchange of possession for rent. ${ }^{16}$ Since the

6. E.g., Neering v. Illinois Cent. R.R., 383 IIl. 366, 50 N.E.2d 497 (1943); Amoruso v. New York City Transit Authority, 12 App. Div. 2d 11, 207 N.Y.S.2d 855 (1960).

7. E.g., Connolly v. Nicollet Hotel, 254 Minn. 373,95 N.W.2d 657 (1959); Schubart v. Hotel Astor, Inc., 168 Misc. 431, 5 N.Y.S.2d 203 (Sup. Ct.), affd, 255 App. Div. 1012, 8 N.Y.S.2d 567 (1938), aff d per curiam, 381 N.Y. 597,22 N.E.2d 167 (1939).

8. E.g., McLeod v. Grant County School Dist., 42 Wash. 2d 316, 255 P.2d 360 (1953).

9. E.g., Viands v. Safeway Stores, Inc., 107 A.2d 118 (D.C. Mun. Ct. App. 1954); Cejka v. R.H. Macy's Co., 155 N.Y.S.2d 565 (Sup. Ct. 1956), rev'd on other grounds, 3 App. Div. 2d 535, 162 N.Y.S.2d 207 (1957), affd, 4 N.Y.2d 785, 173 N.Y.S.2d 24, 149 N.E.2d 525 (1958).

10. E.g., Quinn v. Smith Co., 57 F.2d 784 (5th Cir. 1932) (swimming pool); Pfeifer v. Standard Gateway Theater, Inc., 259 Wis. 333, 48 N.W.2d 505 (1957) (theater). See also St. Julian v. State, 82 So. 2 d 85 (La. App. 1955) (jailor-prisoner); Sylvester v. Northwestern Hospital, 236 Minn. 384, 53 N.W.2d 17 (1952) (hospital-patient).

11. See notes 6,7 \& 8 supra.

12. 147 Wash. 257, 265 P. 472 (1928).

13. 5 IIl. App. 2d 327, 125 N.E.2d 544 (1955).

14. Id. at 548 .

15. See generally Prosser $\S 63$.

16. See Quinn \& Phillips, The Law of Landlord and Tenant: A Critical Evaluation of the Past with Guidelines for the Future, 38 FoRD L. REV. 225, 227-28 (1969). 
landowner was generally not resident on the same parcel, he had no greater control over the premises than his tenant. Although these medieval conditions no longer influence metropolitan lives, they are only now losing their influence over the legal relationship between the urban landlord and his tenant. ${ }^{17}$

Courts generally have proceeded on a tort theory in expanding the duties of the landlord to require him to use reasonable care to assure the safety of the premises retained under his control. Fundamental to the application of this theory is his "retained control" and the corresponding lack of control of the tenants. Thus, the Court of Appeals for the District of Columbia Circuit in Kay v. Cain ${ }^{18}$ affirmed an award to a tenant who fell in an unlighted hallway, stressing the duty of the landlord to use reasonable diligence for the maintenance of areas under his control. This theory was followed in Pessagno v. Euclid Investment Co. ${ }^{19}$ and Robinson v. Park Central Apartments, ${ }^{20}$ both involving falls on icy sidewalks, in which the courts reemphasized the "exclusive control" aspect of Kay v. Cain as the basis for imposing the duty on the landlord. On this same theory, a duty to control third parties has been found to rest upon the landlord. In three cases ${ }^{21}$ involving tenants' children injured by other minors at play on the premises, the courts recognized an affirmative duty on the part of the landlord adequately to supervise persons cngaging in potentially hazardous activities on the common areas of the premises under his control.

The majority of courts have held that the landlord is not liable for the criminal acts of intruders, ${ }^{22}$ although several have found liability, relying upon the similarities between the modern apartment owner and the innkeeper and upon the duty of the landlord to keep the areas

17. See, e.g., Javins v. First Nat'l Realty Corp., 428 F.2d 1071 (D.C. Cir. 1970); Whetzel v. Jess Fisher Management Co., 282 F.2d 943 (D.C. Cir. 1960); Ramsay v. Morrissette, 252 A.2d 509 (D.C. Ct. App. 1969); Bass v. City of New York, 61 Misc.2d 465, 305 N.Y.S.2d 801 (Sup. Ct. 1969).

18. 154 F.2d 305 (D.C. Cir. 1946).

19. 112 F.2d 577 (D.C. Cir. 1940).

20. 248 F. Supp. 632 (D.D.C. 1965).

21. Mayer v. Housing Authority, 84 N.J. Super. 411, 202 A.2d 439 (App. Div. 1964); Gcigel v. New York Housing Authority, 225 N.Y.S.2d 891 (Sup. Ct. 1962); DaRocha v. New York Housing Authority, 109 N.Y.S.2d 263 (Sup. Ct. 1951), aff d, 282 App. Div. 728, 122 N.Y.S.2d 397 (1953).

22. E.g., Applebaum v. Kidwell, 12 F.2d 846 (D.C. Cir. 1926); Goldberg v. Housing Authority, 38 N.J. 578, 186 A.2d 291 (1962). Landlords have been held liable for the criminal acts of their employees against tenants. Kendall v. Gore Properties, lnc., 236 F.2d 673 (D.C. Cir. 1956). 
under his exclusive control safe. In Ramsay $v$. Morrissette, ${ }^{23}$ the landlord originally employed a resident manager to watch over the common areas but, upon the manager's death, failed to hire a permanent replacement. Although warned that conditions on the premises were degenerating and that vagrants were sleeping in the hallways, the landlord neglected to improve the situation. After a tenant was assaulted by an intruder, the District of Columbia Court of Appeals indicated that there was a duty to provide some protection against attacks by intruders. ${ }^{24}$ In reaching its conclusion, that court relied on Kay v. Cain ${ }^{25}$ and, on the authority of Kendall v. Gore Properties, Inc. ${ }^{26}$ extended the duty of the landlord to require him to restrain third persons. In Kendall, the landlord hired a painter, knowing only that he worked "at the Air Force," and allowed him to work unsupervised in the apartment of a female tenant whom he strangled to death only one day later. Holding the landlord liable, the court noted that he was under a duty "to take such steps as an ordinarily prudent person . . . would have exercised to avoid injury to his tenant . . . "27 In Bass v. City of New York ${ }^{28}$ the court held that a landlord who once undertakes police surveillance must then maintain it with diligence lest his tenants rely to their detriment on the earlier level of protection. A case which on facts analogous to Ramsay and Bass does not impose liability on the landlord is Goldberg $v$. Housing Authority, ${ }^{29}$ where plaintiff, a milkman, was robbed and beaten in midafternoon in one of defendant's self-service elevators. Even though the landlord had knowledge of numerous prior acts of a similar nature, there was only one special policeman assigned to patrol the entire 6,000 tenant complex during the time the attack occurred. The Goldberg court limited its decision to a holding that the landlord is under no duty to hire special police, thus avoiding the more difficult question of whether he need provide any protection at all.

Drawing from this line of precedent, the court of appeals in Kline v. 1500 Massachusetts Avenue Apartment Corp..$^{30}$ restated the rule that a landlord must use ordinary care and diligence to assure the

23. 252 A. 2 d 509 (D.C. Ct. App. 1969), noted in 48 N.C.L. Rev. 713 (1970).

24. Id. at 512 .

25. 154 F.2d 305 (D.C. Cir. 1946).

26. 236 F.2d 673 (D.C. Cir. 1956).

27. Id. at 680 .

28. 305 N.Y.S.2d 801 (Sup. Ct. 1969).

29. 38 N.J. 578, 186 A.2d 291 (1962). See also 38 N.Y.U.L. Rev. 784 (1963).

30. No. 23,401 (D.C. Cir. Aug. 6, 1970). 
reasonably safe condition of the areas reserved for the common use of his tenants ${ }^{31}$ and, citing Kendall v. Gore Properties, Inc. ${ }^{32}$ brought the predictable criminal acts of intruders within the circle of dangers from which the reasonably prudent landlord will protect his tenants. While acknowledging the general proposition that a private person has no duty to protect another from criminal attacks, the majority refused to apply it to the facts of the case, recognizing instead the similarities between the innkeepers in Gurren ${ }^{33}$ and Fortney ${ }^{34}$ and the multi-unit apartment landlord in Kline. Since both the apartment tenant and the hotel guest have entrusted themselves to the care of others in better positions to insure that proper precautions are taken, the court placed a similar duty of protection upon the landlord as on the innkeeper; "there is implied in the contract between landlord and tenant an obligation on the landlord to provide those protective measures which are within his reasonable capacity." 35 With the existence of a duty established, the court determined that the appellee failed to meet the standard of care which was defined as "reasonable care in all the circumstanees." ${ }^{38}$ To the anticipated charge that crime deterrence is a police function, the majority pointed out the sheer inability of public authorities to patrol all the corridors of a large city and noted the frequent overlap of civilian and police responsibilities. That the cost of these preventive measures will be passed on to the tenants was recognized and viewed as a beneficial exchange for the elimination of human suffering and increased insurance premiums which crime engenders. ${ }^{37}$ The dissenting opinion, while sympathizing with the "hysteria of apartment dwellers in an inner city plagued with crime," 38 would require an express contractual basis for any police protection desired by tenants, since an injustice to the landlord results if a tenant may recover for an injury arising out of a danger of which he was fully aware.$^{39}$ The dissenting judge contended that the plaintiff had not proved that the landlord was on notice of a dangerous

\footnotetext{
31. See, e.g., Kay v. Cain, 154 F.2d 305 (D.C. Cir. 1946).

32. 236 F $2 d 673$ (D.C. Cir. 1956).

33. Gurren v. Casperson, 147 Wash. 257, 265 P. 472 (1928). Sec text accompanying note 12 supra.

34. Fortney v. Hotel Rancroft, Inc., 5 Ill. App. 327, 125 N.E.2d 544 (1955). See text accompanying note 13 supra.

35. No. 23,401 at 14 .

36. Id. at 15; see Kermarec v. Compagnie Generale Transatlantique, 358 U.S. 625 (1959)

37. No. 23,401 at 21.

38. Id. at 29 (MacKinnon, J., dissenting).

39. Id.
} 
situation, since, according to the record, there had been only one act of violence on the premises prior to the Kline assault. He argued that since the plaintiff's tenancy was on a month to month basis, the relevant standard to determine the level of protection implied in contract was that of the current month..$^{40}$ Finally, the dissent attacked the court's reliance on Gurren and Fortney, noting especially that, in the former case, the court found liability only where a guest expressly requested protection from the threats of a specific guest.

In Kline, the court of appeals focused upon the coalescence of tort and contract principles; hence, the precise foundation for the duty it imposes is difficult to characterize. The court is most persuasive in its tort analysis, although its reliance on the innkeeper analogy is questionable since no case is cited where the hotel owner was obliged to safeguard his corridors from the criminal acts of unknown intruders. The majority is more convincing, however, when it concentrates on the fundamental principles of tort law. The concept of control is central to the imposition of the duty of care, for it is only reasonable that he who has control of the premises must make them safe for those lawfully upon them. To assert that "safe" implies "safe from the predictable criminal acts of intruders" is innovative but not illogical..$^{41}$ In spite of the apparent adequacy of the tort theory, the court utilizes contract principles to further sustain the imposition of the duty of care. If an implied contract imposes upon the landlord a duty to provide those security measures "within his reasonable capacity," 42 it is difficult to distinguish this duty from the duty found on the basis of the tort theory. If, however, the duty of the landlord imposec' by implied contract is only to "keep the premises in their beginning condition during the lease term," 43 as the court later intimates, the holding is limited by the facts of the case, and no duty in contract would rest upon a landlord who fails from the outset to institute protective measures. The court's desire to announce a contractual basis for the duty, when an adequate tort basis is available, may stem from an inclination voiced in Javins $v$. First National Realty Corp. ${ }^{44}$ and reaffirmed in Kline to treat urban

\footnotetext{
40. Id.

41. E.g., Restatement (Second) of Torts $\S \S 302 \mathrm{~B}, 314 \mathrm{~A}(3), 314 \mathrm{~A}(4)$, Comments $\mathrm{e}$, f; Caveat to § 314A; § 315(b) (1965).

42. No. 23,401 at 14 .

43. Id. at 15 .

44. 428 F.2d 1071 (D.C. Cir. 1970).
} 
apartment leases not as property conveyances but as contracts. By this analysis the law of urban landlord and tenant is removed from the relatively rigid concept of property law and allowed to adopt the more flexible principles governing contracts for the sale of goods and services. ${ }^{45} \mathrm{ln}$ addition, on the facts of the instant case, an action on the contract might have been brought-prior to any personal injury to the tenant.

Focusing on the breadth of the holding in Kline, that an urban landlord must take reasonable steps to protect his tenants from the foreseeable criminal acts of third parties, it is immediately obvious that the required level of protection will necessarily be highest in the poor, crime-ridden areas of our central cities. There, the predictability of criminal activity may be so great that only costly and elaborate security devices and private police patrols will satisfy the "reasonableness" requirement of the majority's holding. For those apartment complexes leasing to persons of average means, such a duty may be reasonable, for the tenants are capable of absorbing the higher costs of 24 hour guards and expensive security equipment. Similarly, tenants of public housing projects would benefit from the imposition of such a duty so long as any increased cost is born by the tenant qua taxpayer rather than by the tenant qua tenant. But those unable to obtain public housing and already disadvantaged by relegation to the "inner city plagued with crime" 46 are further burdened by the added costs of protective measures..$^{47}$ Yet one can agree with the court that in the context of the multi-unit dwelling the costs of reasonable security precautions to any single tenant may be far outweighed by the benefits he will reap from them..Even so, there is an intuitive reaction against compelling those in the inner city to finance their own protection when those in other areas may safely rely upon the tax-supported civil authorities ${ }^{48}$ Until united community action programs function to prevent crime, we must settle for such measures as those enunciated in Kline which at least aid the urban dweller in his attempt to pursue a life free of the terror of unrestrained crime.

45. As an alternative theory, the majority intimates that the concept of the implied warranty of habitability recently reemphasized in Javins may apply to the facts of Kline, and indicates that reasonable security precautions may be within that package of conditions which constitutes habitability.

46. No. 23,401 at 29.

47. See Goldberg v. Housing Authority, 38 N.J. 578, 591, 186 A.2d 291, 298 (1962).

48. Should rent controls or similar legislative devices be in effect, the burden will not even be shifted to the tenant but will remain upon the landiord. 